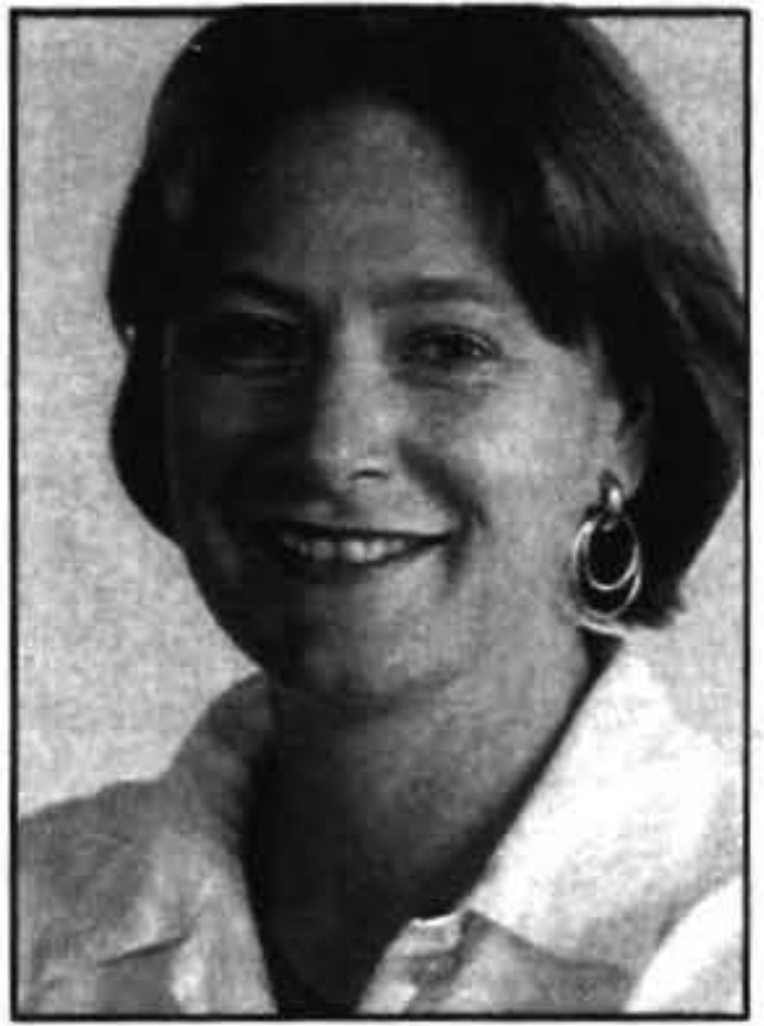

\title{
THE IMPACT OF THE ECA ON \\ LABOUR RELATIONS IN HOTELS AND RESTAURANTS
}

\author{
Rose Ryan \\ Industrial Relations Centre \\ Victoria University of Wellington
}

\begin{abstract}
Since the passage of the Employment Contracts Act in 1991, there has been much debate in New Zealand about prevailing patterns of labour relations. It has been suggested that distinctions can be drawn between those workplaces where the Act has been used to exploit workers in a disadvantaged labour market position, those where the Act has been used to develop more positive relationships, and those where little change has been experienced. The service sector in general, and the hospitality industry in particular, is often used as an example of the first of these three strategies but usually first on the basis of anecdotal evidence. This paper looks more widely at the question of labour relations practices, reporting survey evidence from 1100 workplaces in the "Accommodation Cafes and Restaurants" industrial sector in New Zealand, followed up by interviews with managers in the industry. It focuses on the nature of employment contracts, wage determination, and representation in the industry. It concludes that the prevailing pattern of labour relations should be characterised not as exploitative, but rather as a form of benevolent paternalism. It also concludes that there is little evidence to support the contention that the ECA has resulted in an increased amount of real negotiation in the industry.
\end{abstract}

The environment surrounding the Employment Contracts Act (ECA) in New Zealand has been controversial since its passage in 1991. Much has been claimed for the Act, including increased levels of employment and productivity, and a reduction in industrial action. While some of these claims are difficult to prove or disprove (see for example, Henning, 1995; Yeabsley and Savage, 1996) an indisputable feature of change during the 1990s has been a decentralisation of industrial relations to the level of the workplace. The most common type of collective employment contracts are those established at an enterprise level (Industrial Relations Service, 1996; Harbridge and Crawford, 1996) and it has been estimated that just under a third of the workforce are employed under individual employment contracts (Statistics New Zealand, 1993).

Despite this change, employer approaches to industrial relations in the past five years are still a matter for debate. While some have claimed that the Act has allowed more positive relationships to develop between employers and employees, others have argued that the Act has facilitated a more aggressive approach to industrial relations based on exercise of unconstrained managerial prerogative. Attempts have been made to estimate the spread of various practices (see for example Boxall, 1993, 1995; Heylen Research Centre, 1992, 1993), but in general little is known about the ways in which individual employers have approached the transition to enterprise based bargaining.

The service sector in general, and the hospitality industry in particular, is generally used to illustrate the ways in which employers have made use of new-found freedoms to take advantage of workers in a disadvantaged labour market position (Gosche, 1992; Harbridge and Street, 1995). While these studies are important in providing an understanding of the impact of the Act from an employee perspective, they paint only a partial picture of the dynamics of workplace industrial relations. This paper aims to add to our understanding of labour relations practices by reporting survey evidence from 1150 workplaces in the "Accommodation Cafes and Restaurants" industrial sector in New Zealand and interviews with managers in the industry. It focuses on the nature of employment contracts, wage determination, and representation in the industry. It concludes that there is little evidence to support the contention that the ECA has resulted in an increased amount of real negotiation. It also concludes, however, that the prevailing pattern of labour relations in the industry should be characterised not as expioitative, but rather as a form of benevolent paternalism.

\section{Management practice in industrial relations}

Research into aspects of management industrial relations practice dates back to the 1960s, stimulated by Fox's (1966) now well-known distinction between unitarism and pluralism. To recap briefly, the unitarist approach saw workplaces as meeting only management interests and as responding to only one source of authority; while a pluralist approach accepted the notion of competing interests between workers and managers, viewing organisations as coalitions of individuals and groups. Academic debate on the proposed 'frames of reference' continued through the 1970s. Criti- 
cisms centred around concerns that it was overly simplistic, and needed to incorporate a radical perspective, and led to several re-workings of the model (see for example, Fox, 1974; Clegg, 1979).

As the 1980s saw the balance of bargaining advantage turn in favour of employers, managers and managerial style increasingly became part of the industrial relations research agenda, and several typologies of management approaches were developed. The most significant development in this respect was Purcell and Sisson's (1983) model which argued that distinctions centred around the extent to which managers worked with trade unions, and the extent to which employment policies promoted the interests of employees as individuals or groups (see Figure 1 below). In contrast to Fox, Purcell and Sisson argued that it was possible for some employers to both work with trade unions and have 'good' employee relations policies (as in the case of consultative employers) while others adopting a more traditional approach were opposed to dealing with trade unions, and adopted an exploitative stance towards their employees.

The model has undergone further refinement, and a number of other typologies have been developed in the course of the 1980s and 90s (see for example Purcell, 1987; Guest, 1990; Marchington and Parker, 1990; Purcell and Ahlstrand, 1993). In particular, some commentators have expressed the view that a focus on trade unions may reflect the industrial relations concerns of an earlier period, and that the model may be too static to explain changes in management approach that have taken place over recent years (Storey and
Bacon, 1993). In response to the first of these criticisms, Purcell and Ahlstrand (1993) have suggested that a focus needs to be placed on management approaches to their employees as individuals (specifically to the extent to which they treat employees as a resource/investment or whether they focus on reducing labour costs) and as a group (particularly whether they adopt a cooperative or adversarial approach). As can be seen from Figure 2 on the next page, this allows for a wider range of possibilities in management approach than that suggested in earlier times.

Other commentators on management approaches to industrial relations have focused on the extent to which approaches to industrial relations have changed as the balance of bargaining advantage has reversed in favour of employers. Although there is little agreement on the words used to describe different classificatory systems, a number of commentators (Batstone, 1988; Baglioni, 1990, Horstman, 1988) have suggested three (very broad) approaches as industrial relations environments have diversified. These have included those employers who have continued their employment practices largely intact; those who have developed more sophisticated human resource management type policies, either with or without unions; and those who have used the economic circumstances of the 1980 and 90 s as an excuse to adopt 'macho' management practices based on a reassertion of managerial prerogative. A similar approach has been adopted in New Zealand, in respect of employer practices following the passage of the Employment Contracts Act in 1993. Boxall (1993) hypothesised the existence of three types of employer strategy in the early 1990s

\section{Figure 1. Dimensions of management style}

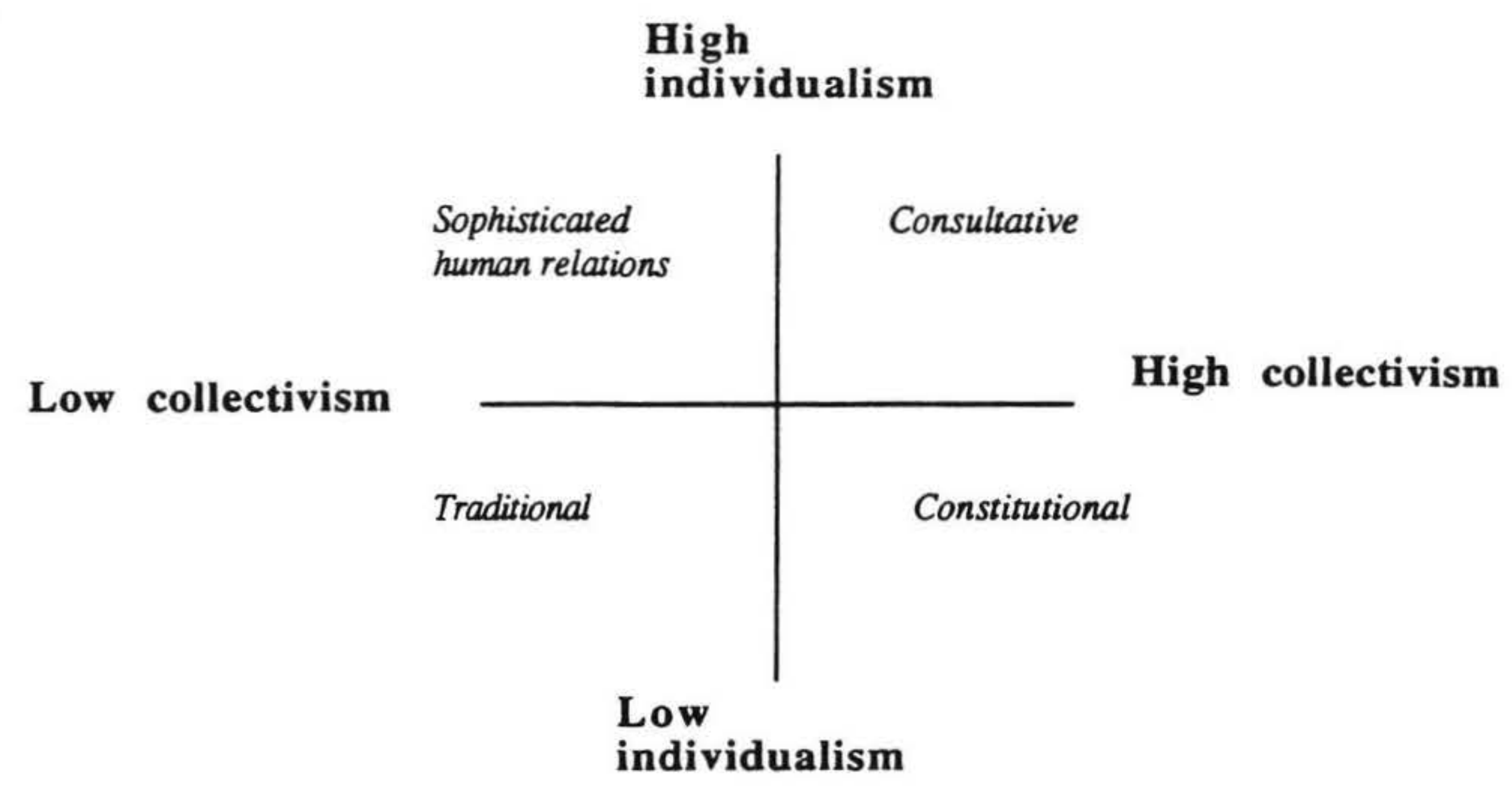

Source: Sisson, 1989 
Figure 2. Alternative approaches to management style

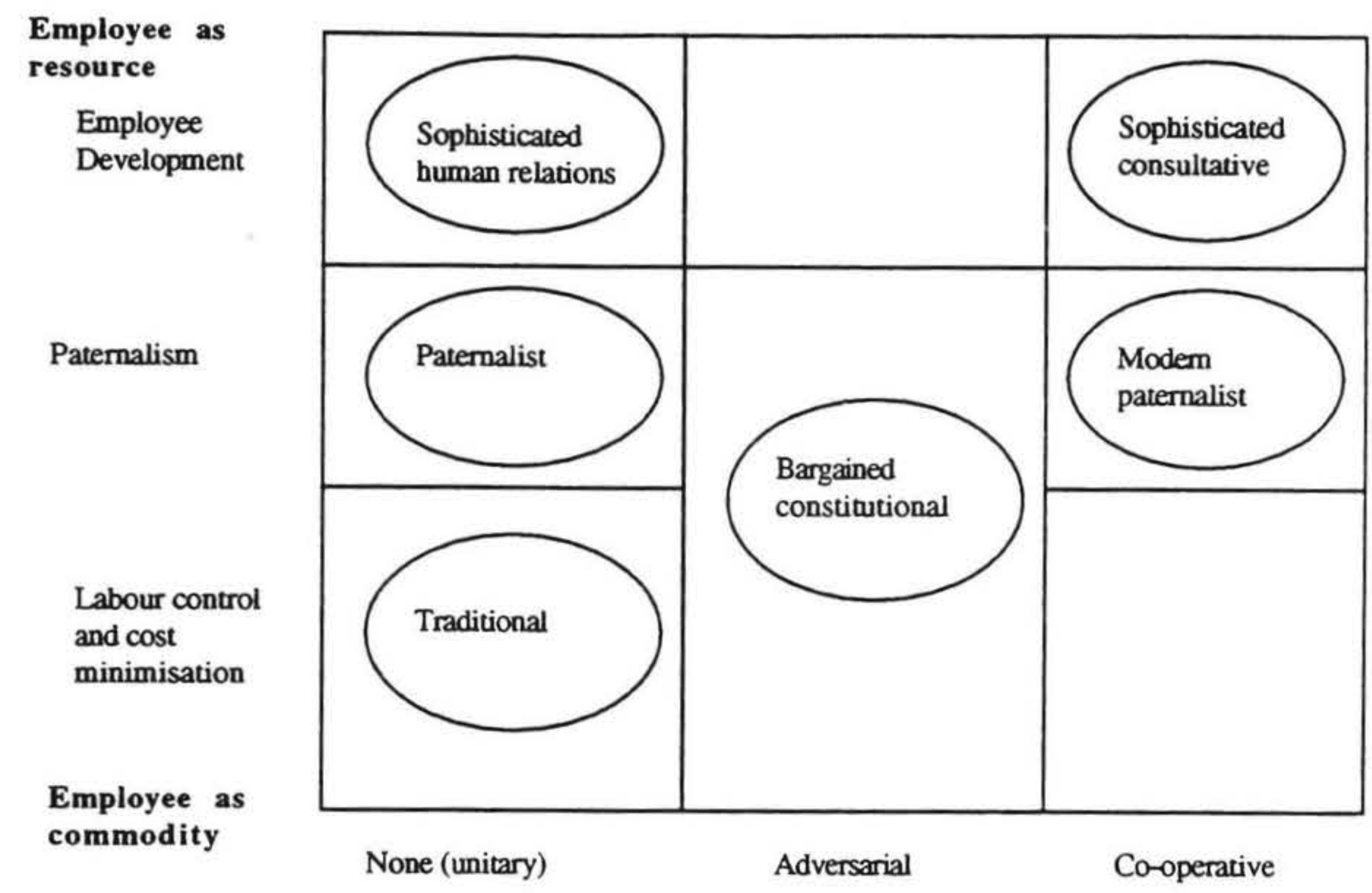

COLLECTIVISM

Source: Adapted from Purcell, 1987; Storey and Sissom, 1994;

Purcell and Ahlstrand, 1993

(mainstream employers who had changed little in their employment practices, those who used the Act to drive down wages and conditions, and those pursuing a high-trust strategy) although more recently he has claimed that 'most' employers have acted behaved reasonably (Boxall, 1995). In addition, Heylen Research Centre has conducted a factor analysis of survey data to suggest that a range of enterprise types could be distinguished (see Heylen, 1992, 1993; Armitage and Dunbar, 1993; Whatman, Armitage and Dunbar, 1994). Neither of these typologies, however, have attracted significant debate, nor has there been systematic analysis of the veracity of these patterns, why employers in similar circumstances adopt different practices, and how they have changed over time.

The research reported here has been designed to take an indepth look at a range of employment, work and industrial relations patterns in one industry sector in New Zealand. It has focused particularly on the reasons which employers and managers advance to explain why they adopt the particular practices that they do. This paper focuses on industrial relations practices, in particular the approaches that have been adopted in respect of wage determination and contract negotiation; and the extent of unionisation and representation in the industry.

\section{Research methodology}

The study on which this paper is based was carried out from mid 1995 through 1996, using a combination of survey and follow-up interviews. The survey was sent to a sample of workplaces in the 'Accommodation Cafés and Restaurants' industrial sector, selected at random off the Statistics New Zealand Business Directory. "While this sample frame is unquestionably the most reliable one, it does, however, have limitations. The first is that there is inevitably some lag between the time that businesses are started up and the date of their inclusion on the Business Directory. Given the rate of growth in the hospitality industry, and a rate of business startup and demise is higher than other industries, this may be more of a problem in this industry than it is in others. Secondly, the Business Directory only includes businesses with an annual GST turnover or expenses of greater than $\$ 30,000$, or employing two or more employees. Therefore the sample frame may miss out on failing businesses or extremely small ones.

The survey was posted out in late 1995 , to a sample of 1150 firms stratified by size. Of the 1150 questionnaires distributed, 698 were returned. This represents a response rate of $60.7 \%$ which is very good for a postal survey of this type. Only 560 of these responses ( $49.7 \%$ of the total sample) were usable however, as is indicated above.

Completed questionnaires were received from a wide range of workplaces across all sizes, locations and industry subgroups (see Figure 3). It is impossible to definitively establish whether the sample is fully representative of the industry as a whole, as Statistics New Zealand publishes its statistics according to a different classification. However, estimates from the Business Activity statistics published by Statistics 
conducted at 37 workplaces, across a range of industry subsectors, size groups and locations. Interviews were semistructured, following a pre-set list of subject areas, but being wide-ranging in specific content. All interviews took place at the interviewee's workplace, and ranged in length from half an hour to an hour and a half, with most taking 45-50 minutes. All interviews were tape recorded.

\section{Bargaining and wage determination}

The survey asked a series of questions related to the employment contracts applying at the workplace, the process by which these were negotiated and the ways in which wages for employees were determined. More detail about these issues was sought in interviews. The picture that emerged was one which was positive in respect of the number of workplaces which had established comprehensive written employment contracts, but less so in respect of the process by which these contracts were established.

A surprisingly high proportion of employment contracts $(56.2 \%)$ were written. Only $26 \%$ of workplaces had solely verbal contracts, although in a further $17 \%$ there is a combination of verbal and written contracts. The existence of written contracts was closely related to workplace size, and only in workplaces employing fewer than five employees did a majority have verbal contracts. Over two-thirds of workplaces employing more than 15 employees had written employment contracts, as did workplaces that were associ-

Figure 3. Respondents by industry sub-sector

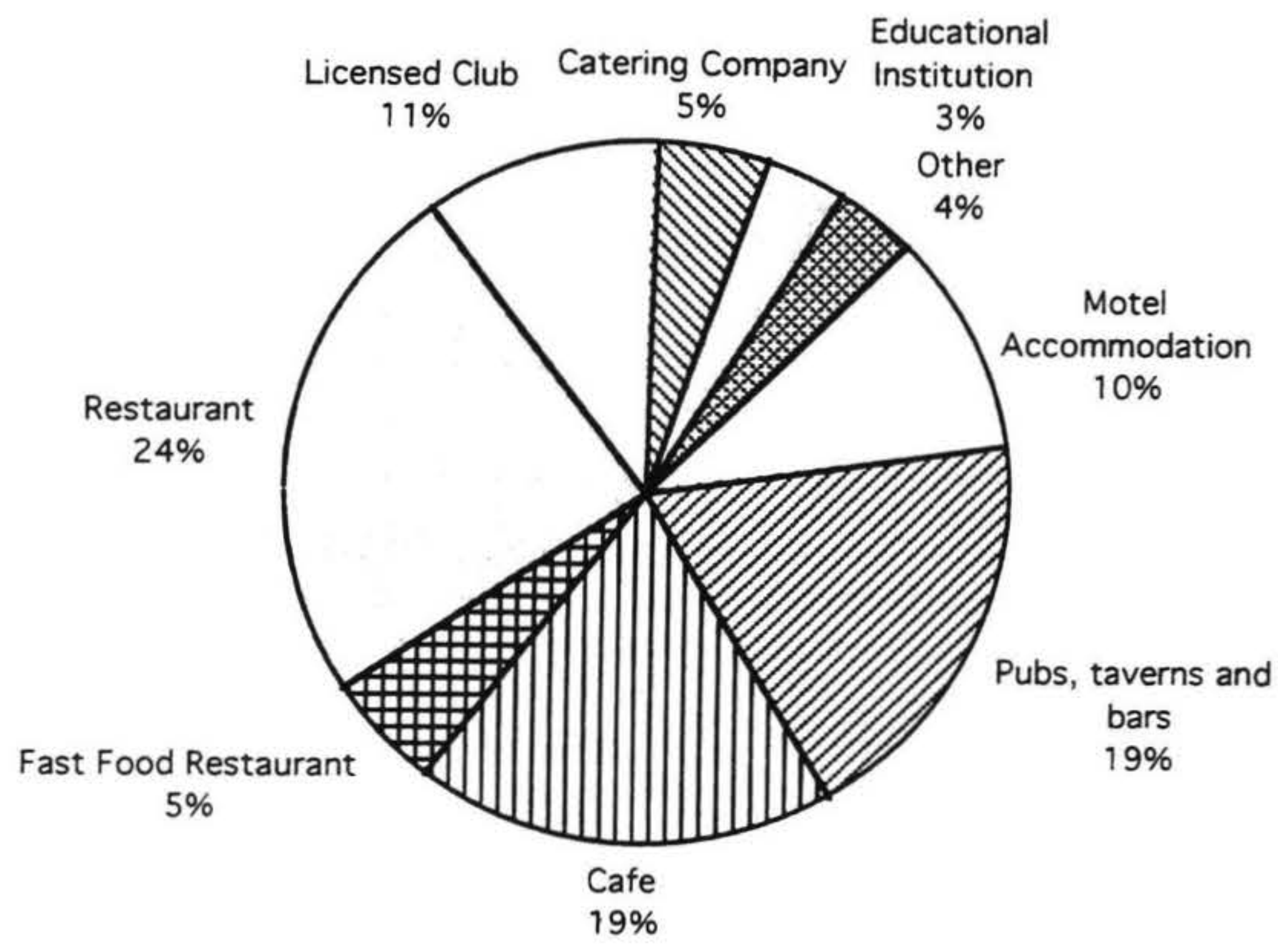


ated with a larger organisation (such as franchises, clubs belonging to an association, or workplaces which were part of a chain operation).

The process of establishing these contracts, however, does not generally constitute a negotiation. Table 2 shows survey responses to a question asking managers to describe the nature of employment contracts applying at the workplace.

As can be seen from Table 2, even by managers' own accounts, the most common pattern was for employment contracts, whether individual or collective, to be determined by management. A similar pattern was seen when managers were asked how the rate of pay was decided upon for individual employees. In $41.5 \%$ of workplaces managers

\section{Table 2. Nature of employment contracts at the workplace}

\begin{tabular}{lcc}
\hline Type of contract & Number & Percent \\
\hline Union negotiated CEC & 33 & 6.3 \\
Employee negotiated CEC & 26 & 4.9 \\
Management determined CEC & 111 & 21.1 \\
Management determined IEC & 103 & 19.6 \\
Individually negotiated IEC & 37 & 7.0 \\
Standard IEC with some & & \\
$\quad$ individual variations & 91 & 17.3 \\
Mix of IECs and CECs & 93 & 17.7 \\
Other & 32 & 6.1 \\
\hline$N=526$ & &
\end{tabular}

$N=526$

replied that they decided on the rate of pay and informed the employee. In a further $29 \%$ of cases employees were paid a standard rate of pay set out in the contract, and in $30 \%$ of workplaces, employees individually negotiate a rate of pay with the employer. Again, size proved to be an important variable influencing the pattern of contracts and the process of wage setting. Collective rather than individual contracts were associated with increasing workplace size, and workplaces that were associated with a larger organisation. Workplaces with between 30 and 49 employees were more likely than others to be employed under a union negotiated contract, but the collective contracts in workplaces employing more than 100 employees were more likely to have been negotiated by employee representatives. In addition, and not surprisingly, standard rates of pay were more likely to be paid in workplaces where a collective contract was in place.

The nature of employment contracts was also associated with industry sub-sector. Hotels, fast food restaurants, licensed clubs and catering companies were more likely than others to have written contracts, and to pay according to standard rates of pay. While in most industry sub-sectors the most common pattern was for employment contracts to be determined by management, this was not true for restaurants. Interestingly, in this sector $40.6 \%$ of workplaces reported individually negotiated variations to standard individual contracts, and a much higher proportion reported that wage rates were set by negotiations with individuals.

In follow-up interviews, managers were asked in more detail about how they decided on wage rates and the structure of their contracts. The comments that they made suggested an approach to employees which could not so much be characterised as focusing on cost-cutting, but rather on achieving value for money. In making decisions about wage rates, and in negotiating with individuals for wage increases, managers frequently referred to assessing whether the employee was 'worth it' based on their experience and skills. Typical were these comments:

... we bring everyone in low and say, well you've got two weeks. You're on this wage and if I think you're worth it then I'll take you up. Its kind of an unfair system, but I see it as very fair in the way that I do it. Basically someone will come in and they'll start working ... on $\$ 8.50$ an hour. And when I think that person's trained out front ... some people will go up within the week, some you never see hope and it might be six months down the track. But then they go up to $\$ 9.50$, and then the next rises might be for service or when they get promoted to supervisor, or just generally good work (Cafe Manager).

...for someone younger or with less experience I'll say $\$ 8.50$, it will go up as you learn more. It'll go up to $\$ 9$ or $\$ 9.50$ as that person learns more, because its...you know, if you've got good staff you want to keep them. And so the incentive is the pay increase. I mean they enjoy their job, but if you can offer someone some more money, they're going to be happy with the money as well (Restaurant Manager).

The reasons for deciding on contract structures had not always been considered, and in some instances managers were not clear whether the nature of the contract which they had in place was individual or collective. Where this had been thought through, most managers had opted for individual contracts. Many saw it as symbolic of the personal service nature of the industry, and saw individual contracts as being a way of establishing closer relationships with staff. When asked about his preference for individual rather than collective contracts, one manager replied:

Its more of a personal contact with the staff member, saying ... this is the employment contract with holidays and rates of pay, y'know. It actually sits a person down as an individual and says, well, these are the rules we have. You have a copy. Read them and talk about them. Its just a personal ... y'know because we have so few employees it's quite easy. I treat them as a person, as an individual, rather than say "Okay you're under the collective contract, here's a copy" (Hotel Manager).

Employment contracts applying in those workplaces where interviews were carried out were collected wherever possible. The comprehensiveness of these contracts varies considerably. At a minimum they included hours of work, wages, annual leave provisions, personal grievances and disputes. Some are little more than a page, setting out hours 
of work and rate of pay, although these were generally contracts which applied to casual staff employed for functions. However, a surprising number were more comprehensive contracts which included rest breaks, rostering provisions, annual and statutory holidays, sick and bereavement leave, disciplinary procedures, long service leave, and work rules. Only a very small proportion make provision for allowances of any kind, and provision for penal or overtime rates of pay are virtually non-existent. The comprehensive nature of many of these contracts may be attributed to the fact that the Hospitality Association and the Chartered Clubs Association have both provided their members with standard contracts, which were used by a high proportion of interviewees as the basis for establishing their workplace contract. In addition, a number of interviewees stated that they had used the relevant award as the basis for establishing a new contract of employment in the period after the Act. Two managers described the way in which they did this:

We have an employment contract for full and part time staff which is loosely based on the Hotel Association standard contract and the award, which we've amended very slightly. I think the only changes we've made ... from memory ... special leave comes in after one year, I think they have six months. And we have a special clause in there to do with fire regulations which of course people are very hot on these days (Hotel Manager).

We historically went right back to the standard hourly rate - the award - and when we came to that very first negotiation which was changing from the award structure to an individual contract and a flat hourly rate. And we did a basic equation, and we said "well lets take $\mathrm{X}$ employee. Lets look at how many hours they worked in a full twelve month year, including all public holidays, all weekends" and we tried to pick people who were working both work days and weekends ... And we divided that up to get a new hourly rate. So all we said to them was, if I then took that hourly rate, which is higher than the award and paid you that for any hour worked, you would actually get exactly the same as if you were on the award. And I took that and said, "we would like to move away from the award" and to make that attractive, from our point of view, we raised (the hourly rate) (Motel Manager).

A number of managers, however, displayed a degree of misunderstanding about what they could and couldn't include in their contract. The follow-up interviews found managers who believed that there was still an award, that the Hospitality Association prescribed wage rates for the industry which they were obliged to pay, and that they could negotiate away statutory holidays with the consent of employees. The managers who were interviewed frequently stated their commitment to their employees, but many had a limited understanding about what was required of them by law, or what they could do in respect of their employment practices. This meant that they were often vulnerable to being given poor advice. Employers who had attempted to put in place innovative practices, for example, had been advised by their lawyers not to move outside legislative minimum conditions of employment; and others had taken out insurance against personal grievances on the advice of insurance brokers who had exaggerated the circumstances in which employees could claim unjustified dismissal and the amount of compensation that employers might be required to pay. In these circumstances, a number of employers had opted to 'play safe', and decisions about the content and nature of employment contracts were made on the advice of lawyers and accountants, rather than by negotiation with employees.

\section{Representation}

An additional part of the research looked at employer and employee membership and representation by other organisations. It confirmed the widely held view of the industry as having a low level of union density, but revealed a high level of dependence by employers on receiving outside expert advice.

Employers were asked in the survey about the percentage of their employees who belonged to the union. Although it is accepted that managers may not have accurate knowledge of the actual levels of union membership two thirds of respondents said that they had no union members at their workplace, and $18.4 \%$ had up to half. In only $3.6 \%$ of workplaces were more than half the number of employees members of the union. The areas in which union membership was strongest were Licensed Clubs and Catering companies, and to a lesser extent, major accommodation hotels, while union membership was lowest in restaurants and cafes. Other measures indicated a low level of union activity. In just over $10 \%$ of workplaces had unions made an attempt to recruit members at the workplace in the past year, and in a similar number the union had raised an issue with management on behalf of an employee. Few managers, in interviews, had had any dealings with the union, and a number said that while they had had contact with them in the past, this had dropped off significantly in the post 1991 period.

While managers in the hospitality industry are sometimes characterised as being anti-union, this attitude was not displayed by interviewees. The attitude of most managers to unions and union officials was characterised by complete indifference. Where feeling was expressed in any direction, it was largely positive rather than a negative one. Several managers praised the professionalism of the union officials with whom they had contact, and reported that they had used the union as a source of advice in situations where they had had difficulties with individual employees.

I don't have a problem with the union. I don't care whether we have a union or not. If I had a problem with a dismissal and that person's been a union member, I've sought advice. Because if you involve the union at the right time, then the union will be helpful, because they want to see their work ... they want to succeed as well. Its a matter of trust (Fast Food Restaurant Manager).

In addition, many managers had themselves at one time been employees in the industry and argued the need for a strong 
union given the pervasiveness of poor management practice. They did, however, tend to attribute industrial relations problems to 'other managers', and saw themselves as being better than average employers.

(If the union wanted a meeting with employees) ... we'd say fine, we can't really stop them. I believe there's nothing here, in the contracts, that would contravene ... Everybody's treated fairly. Pay-rates are probably a little above the award (Hotel Manager).

We have not seen them since the Employment Contracts Act started, not even to bring in any information. When the ECA was first proposed we said to the staff, we believe in unions and we think you should stay members of the union. It costs you a pittance, and you never know when you're going to need it. And of the 12 people we were employing then, one person chose to keep paying union fees (Restaurant Manager).

Several interviewees, mostly in large organisations, reported that in the absence of the union, they had developed mechanisms for in-house representation. Very rarely did these mechanisms involve a formal employee organisation however, What was more common, was that at the time that the collective contract was due to be negotiated, management would ask employees to select one or more of their number to negotiate with. This was most commonly achieved through individuals volunteering to do the job, but in addition, it was not uncommon for owners or managers to participate in their selection. In the workplaces where this had been put in place, managers invariably reported that they had had no difficulties in attracting volunteers.

There's never any problems about finding a representative. What we try and do is to make sure we've got a really good cross-section of people. So we've got some older people, some younger people, some full-time and part-time workers, and we put up the list. If we select, we select the people basically so that we've got a spread of people, like we've a manager in there, because they're on the time card as well - they're not all on salary (Fast Food Restaurant manager).

We use volunteers ... those that are interested, usually no coercion, and a lot of them. You'd be surprised at the people that want to be on - people that don't normally volunteer for anything else, but are really interested in that area. You know, chefs, kitchen hands, telephonists - people that you might not think would be interested because of the level of the job that they are doing. But we ask for volunteers and we say to them - look this is for your benefit, its not only for the benefit of management (Hotel Manager).

While only a small proportion of employees belonged to an employee organisation, a larger number of employers belonged to an employer body. Only just over a quarter of respondents did not belong to any employer organisation, and a high proportion belonged either to the relevant industry body (e.g.; the Hospitality Association, Motel Associa- tion of New Zealand, Chartered Clubs Association) or to an employer organisation (e.g.; the New Zealand Employers Federation or a constituent Employer Association) or to both. Those that did not belong to any employer group were generally those employing fewer than 10 staff. Fewer than $30 \%$ of respondents, however, had sought advice on industrial relations matters from the organisations they belonged to. Of those who had, the most common sources for advice were the NZ Employers Federation (used by $7.5 \%$ of respondents) and the Hospitality Association of New Zealand (used by $6.4 \%$ of respondents). Lawyers and accountants were another common source of advice, used by $6.4 \%$ and $3.8 \%$ of respondents respectively. The issues on which advice was most likely to be sought included terms and conditions of employment $(65.7 \%)$, application of the Holidays Act (48.3\%) and dismissals (46.7\%). Respondents selected their source of advice depending on the nature of the problem facing them. The NZ Employers' Federation was the most common source of advice on pay issues, and was also commonly used for advice on dismissals. The Hospitality Association was used for advice on health and safety issues, information about the Holidays Act, and about ACC. Lawyers were used in respect of advice about dismissals and about negotiations with unions, while accountants were used to advise on ACC and pay issues.

\section{Discussion}

The data presented above suggests four main conclusions about the nature of representation and bargaining in the hospitality industry in New Zealand. The first is that despite concern about the vulnerability of workers in this sector being unaware of their employment conditions and rights and with largely verbal contracts, the evidence here is that employment contracts are in fact written down, and in general cover a wider range of matters than simply wages and hours. It must be noted, however, that an analysis of the content of those contracts leaves a less optimistic picture. While contracts generally include a comprehensive range of provisions, these are frequently not much more beneficial than that which is required by legislation. This picture is supported by analysis of employment contracts held at the Industrial Relations Centre (see Harbridge and Crawford, 1996), which suggests that employee entitlements in hospitality industry contracts are below average for wage levels, call back payments, and overtime and penal rates. Other provisions such as parental leave are determined by the legislated standard conditions, and a higher proportion of hospitality than other industry contracts provide for the granting of sick and domestic leave to be at the employers' discretion.

A second conclusion to be drawn from the data is that the data rejects any suggestion that the ECA has resulted in a increased involvement of employees in the process of determining their own wages and conditions. In this industry, irrespective of whether the contract is collective or individual, the prevailing pattern is for managers to determine the content of the contract, often after consulting with outside advisors. This conclusion will come as no surprise to many. 
Following on from this, a third conclusion is that an examination of industrial relations patterns in the industry reveals the huge gap between the resources of employers and employees in the negotiation process. Employers draw up contracts on the basis of advice which they have purchased from outside experts, and who not surprisingly have their clients' best interest at heart. Employees are on the receiving end of this, and frequently have no awareness of their rights, or possible sources of independent advice. Rather than resulting in improved workplace relationships, the ECA may in fact be argued to have resulted in an increasing gap between employer and employee. One manager described the changes that had taken place in his workplace during the first negotiations after the Act was passed:

There was always a great dependency of trust that what we said was right, but trust wasn't always there, even with some of our staff members who had been with us for a long time. We thought that we had a reasonably good relationship, and we thought we understood it, but when it came down to it, a couple of them ... not all of them but about $30 \%$... there was a feeling of "can we really trust you? What's the situation here? Are we being duped?" ... I think if we scratched the surface ... the gap is wider than it was before all this happened. With the legal ... it has taken away the feeling that was there because its a family business, and the ma-ness and pa-ness has moved out (Motel Manager).

A final conclusion relates to how management style in the hospitality industry can best be characterised. While often epitomised as exploitative, the argument presented here is that managers are paternalist in their approach. When asked to describe their management style, interviewees frequently resorted to words such as 'relaxed' 'hands-on' and 'participative' and commonly used phrases such as "I don't expect my staff to do anything that I wouldn't do myself". They described their relationship with their employees as involving 'give-and-take', and attempted to create a positive working environment in which employees enjoyed their work. They aimed for a cooperative work environment, and professed to be open to employee ideas about how work could be improved. While few could be said to treat employees as a valuable investment, neither did they view labour as simply a cost to be minimised. Their reasons for doing so, however, cannot be said to be altruistic, however, but related clearly to the personal nature of the service that is being handed on to customers. The last word goes to a manager who was responding to a question about his approach to management:

If you provide the right environment, then you'll have the right sort of people working there. If you provide a crappy environment, the customer will get the result of that one way or another. So if you provide the right environment, with leadership and all the things that go with it ... if you like the intangible things ... if you provide that we believe that the customer will get a good experience and that's the key. If you don't provide that, if you don't look after your people, then your people won't look after your customers (Fast Food Restaurant Manager).

\section{Future research}

The study has raised a number of interesting questions about the nature of industrial relations at workplace level in New Zealand. Two questions stand out as being particularly relevant for future research. The first is how management attitudes and practice in the hospitality industry compare to those in other industries in New Zealand. The data does not allow us, for example to conclude that the patterns found here are distinctive, but could just as easily be associated with the smaller than average size of workplace, or the predominance of privately owned establishments. More workplace studies in a range of industries would allow the possibility that some of these conclusions could be drawn.

A second area for future research is in the response of employees to patterns of labour relations. The current research has sought managers only as respondents to the survey and interviews. In the area of labour relations, researchers are ever aware that the experiences of employees and employers may be worlds apart, and that a positive approach from management may not be perceived as such by employees. Thus the perceptions and reactions of employees at the workplace to particular management practices or changes in management behaviour (through in-depth case studies or participant observation) would be a useful adjunct to studies of this type.

\section{Note}

1. The Business Directory is the most comprehensive listing of businesses in New Zealand. It comprises information on all "economically significant enterprises" defined as those with more than $\$ 30,000$ annual GST expenses or with more than two full-time equivalent employees. Information on employers is obtained through and Annual Business Directory Update Survey conducted annually. In addition, the database is updated by receiving feedback from other economic and financial surveys (e.g., Retail Trade Survey); by a monthly birth survey of all compulsorily GST registered businesses (this is the prime source for adding new businesses to the frame) and by media and Building Permit information to capture significant new business starting up. (e.g. new shopping malls).

\section{References}

Armitage, C. and Dunbar, R. (1993) Labour Market Adjustment under the Employment Contracts Act New Zealand Journal of Industrial Relations 18(1):94-112.

Baglioni, G. 1990 Industrial Relations In Europe in the 1980s. In Baglioni, G. and Crouch, C. (eds) European Industrial Relations: The Challenge of Flexibility London: Sage Publications Ltd.

Batstone, E. 1988 The Reform of Workplace Industrial Relations: Theory, Myth and Evidence Oxford: Clarendon Press. 
Boxall, P. 1993 Management Strategy and the Employment Contracts Act. In Harbridge, R. (ed) Employment Contracts New Zealand Experiences Wellington: VUW Press.

Boxall, P. 1995 HRM: A Conceptual Framework. In Boxall,P. (ed)The Challenge of HRM: Directions and Debates in New Zealand Auckland: Longman Paul.

Clegg, H. 1979 The Changing System of Industrial Relations In Great Britain Oxford: Blackwell,

Fox, A. 1966 Industrial Sociology and Industrial Relations Research Paper No 3, Royal Commission on Trade Unions and Employers Associations, London: HMSO

Fox, A. 1974 Beyond Contract: Work Power and Trust Relations London: Faber and Faber.

Gosche, M. 1992 The Impact of the Employment Contracts Act 1991. Paper presented to a seminar The Employment Contracts Act: One Year On Industrial Relations Centre, Victoria University of Wellington, 15 May 1992

Guest, D. 1990 Human Resource Management and the American Dream Journal of Management Studies 27(4):378-97.

Harbridge, R. and Street, M 1995 Labour Market Adjustment and Women in the Service Industry: A Survey New Zealand Journal of Industrial Relations 20(1):23-34

Harbridge, R. and Crawford, A. 1996 The Employment Contracts Act and Collective Bargaining Patterns: A Review of the 1995/96 year. In Harbridge, R., Crawford, A. and Kiely, P. Employment Contracts: Bargaining Trends and Employment Law Update Wellington: Industrial Relations Centre, Victoria University of Wellington.

Henning, J. 1995 The Employment Contracts Act and Work Stoppages New Zealand Journal of Industrial Relations 20(1):77-92.

Heylen Research Centre 1992 A Survey of Labour Market Adjustment under the Employment Contracts Act 1991 Wellington: Industrial Relations Service, Department of Labour.

Heylen Research Centre 1993 A Survey of Labour Market Adjustment under the Employment Contracts Act 1991 (November 1993) Wellington: Industrial Relations Service, Department of Labour.

Horstman, B. 1988 Labour Flexibility Strategies and Management Style Journal of Industrial Rela- tions 30(3):412-431.

Industrial Relations Service 1996 Contract Vol 18 August 1996 Wellington: Department of Labour.

Marchington, M. and Parker, P. 1990 Changing Patterns of Employee Relations Brighton: Harvester Wheatsheaf.

Purcell, J. 1987 Mapping Management Styles in Employee Relations Journal of Management Studies 24(5):533-48

Purcell, J. and Ahlstrand, B 1993 Strategy and Style in Employee Relations Oxford: Oxford University Press.

Purcell, J. and Sisson, K. 1983 Strategies and Practice in the Management of Industrial Relations. In Bain, G.S. (ed) Industrial Relations In Britain Oxford: Basil Blackwell Ltd.

Statistics New Zealand 1993 Employment Contracts Survey Wellington: Statistics New Zealand.

Storey, J. and Bacon, N. 1993 Individualism and Collectivism: into the 1990s International Journal of Human Resource Management 4(3):665-84.

Whatman, R., Armitage, C. and Dunbar, R. 1994 Labour Market Adjustment Under the Employment Contracts Act New Zealand Journal of Industrial Relations 19(1):53-74.

Yeabsley, J. and Savage, J. 1996 What do we know about the economic impacts of the Employment Contracts Act? New Zealand Institute of Economic Research, Address to the "Moving Forward" Conference, Auckland May 151996.

\section{Author}

Rose Ryan is a Lecturer at the Industrial Relations Centre, Victoria University of Wellington. This research is part of a larger project which she has undertaken for a $\mathrm{PhD}$, on patterns of labour management in the hospitality industry. 